\title{
Habitat status of Musa paramjitiana L.J. Singh (Musaceae) : a critically endangered, endemic species in Andaman \& Nicobar Islands, India
}

\author{
Lal Ji Singh ${ }^{1}$, Gautam A. Ekka ${ }^{1}$, Sanjay Mishra ${ }^{1,2}$, C.P. Vivek ${ }^{1}$,V. Shiva \\ Shankar ${ }^{3}$ Mudavath C. Naik ${ }^{1}$ and Fouziya Saleem ${ }^{1}$ \\ ${ }^{1}$ Botanical Survey of India, Andaman \& Nicobar Regional Centre, Port Blair-744102, Andaman \& \\ Nicobar Islands, India \\ ${ }^{2}$ Botanical Survey of India, Arid Zone Regional Centre, Jodhpur-342005, Rajasthan, India \\ ${ }^{3}$ Department of Coastal Disaster Management, Pondicherry University, Brookshabad Campus, Port \\ Blair-744112, Andaman \& Nicobar Islands, India \\ ${ }^{4}$ Corresponding author, e-mail: laljisingh1970@rediffmail.com
}

[Received 17.05.2020;Revised 23.06.2020; Accepted 24.06.2020;Published 30.06.2020]

\begin{abstract}
The habitat and IUCN threat status of Musa paramjitiana L.J. Singh (Musaceae), a critically endangered and endemic species from the Andaman \& Nicobar Islands of India has been reassessed and treated as 'Possibly Extinct'. The taxonomic distinctness of the species and possible methods for its conservation has also been discussed in detail.
\end{abstract}

Key words: Musa paramjitiana, IUCN threat Category, Andaman and Nicobar Islands, Conservation status

\section{INTRODUCTION}

Andaman and Nicobar islands ( $6^{\circ} 45^{\prime}$ to $13^{\circ} 41^{\prime}$ and $\mathrm{E} 92^{\circ} 12^{\prime}$ to $93^{\circ} 57^{\prime}$ ) is a phytogeographically important group of 572 Islands with a total land area of $8,249 \mathrm{~km}^{2}$ with a coastline of 1,962 km and constitute a variety of ecosystems: tropical evergreen forests, wetlands mangroves and coral reefs in India. The area is falling within the IUCN recognized Sundaland Hotspot for Biodiversity conservation, and situated close to the equator and exposed to marine impacts including hyper saline conditions with warm and highly humid tropical climate. Cyclonic winds accompanied by thunder and lightning, are very frequent. January to March have fairly dry weather with scanty of rainfall (Singh et al. 2014).

The genus Musa L. (Linnaeus 1753) belongs to Musaceaeis a most diversified genus and comprises of about 70 species. Wild Musa species are largely distributed throughout tropical Asia, the Pacific Islands, Africa and Australia (Argent 1976; Hakkinen \& Vare 2008, Hakkinen 2009; Singh et al. 2020). Of the 32 species occurring in India, 20 species are endemic. In India, wild species are distributed mainly in Eastern Ghats, Western Ghats, North Eastern India and in Andaman and Nicobar archipelago (Singh et al. 2020). It has been highly differentiated in the Himalayas, especially in the Eastern Himalaya and in the states of North-eastern India (Roxburgh 1814; Haines 1910; Hore et al. 1992; Gogoi \& Hakkinen 2013a, b; Hakkinen et al. 2014; Gogoi \& Borah 2014; Dey et al. 2014; Gogoi et al. 2014). In Andaman \& Nicobar Islands (ANI's), the genus Musa is represented by four wild species vir., $M$. acuminata Colla, M. balbisiana Colla, $M$. indandamanensis L.J. Singh, M. paramjitiana L.J. Singh. Also, two cultivated forms of Musa viz., M. xparadisiaca L. and $M$. textilis Nees are available here with many cultivars of different fruit size and colors (Singh et al. 2020). The present study is mainly based on field observations during 
population assessment, authentic herbarium materials and relevant literature (Singh 2014, 2017; Hareesh et al. 2017; Singh et al. 1998, 2018, 2020; Naik et al. 2019).

Hareesh et al. (2017) assessed and concluded the status of Musaceae in ANI's in a short span of single visit in the Islands in the month of August 2017 (as mentioned in Hareesh et al. 2017). While the ANI's is phyto-geographically important group of 572 Islands, which are disjunctive and separated by sea (Singh et al. 2014), it is impossible to cover most parts of the Islands and early explored localities of ANI's and pursue a detailed study of the distribution of Musa in the ANI's. The poor transport connectivity brings difficulties in accessing the localities of Musa population spread over the Islands. It seems that the observations of Hareesh et al. (2017) is superficial and incorrect as elaborately highlighted in several molecular analyses (Naik et al. 2019; Singh et al. 2020).

Furthermore, it is also noticeable that they did not cite in the publication, the specimens of M. paramjitiana recollected from the locality, thus to be assumed that they could not locate the species in the type locality. Instead they only showed the entire change in the characters of Musa population and synonymized $M$. paramjitiana under M. balbisiana Colla var. andamanica. Nevertheless, the entire changes in characters have not been recorded in population variation in any taxa and do not occur in normal environmental condition. M. balbisiana Colla var. andamanica D.B.Singh, Sreek., T.V.R.S.Sharma \& A.K.Bandyop. was published solely based on horticultural specimen grown under the captive breeding programe in the campus of CARI; Central Islands Agricultural Research Institute (now CIARI; Central Islands Agricultural Research Institute) Port Blair (Singh et al. 1998). In the publication, the authors did not cite any herbarium specimen to relate its natural occurrence in the Islands. In fact, the uncertainty on the identity of M. balbisiana var. andamanica has been much debated since it was described. Considering these, this variety has been recently synonymized under M. balbisiana based on molecular analyses along with taxonomic treatment and re-established the species status of M. paramjitiana (Naik et al. 2019; Singh et al. 2020).

Bohra et al. (2019) had studied the accelerating regeneration of M. paramjitiana at CIARI and stated that they could collect fully mature fruits with seeds from Dhanikhari Experimental Garden cum Arboretumof Botanical Survey of India, Andaman and Nicobar Regional Centre (DEGCA, BSI, ANRC), Port Blair. However, we could not locate any live specimens there. As per DEGCA, BSI, ANRC record, only few rhizomes and seedlings (collected from type locality) of M. paramjitiana were transplanted by the protologoue author in 2013 but failed to survive. While studying on the genus since 2010, till date, the present authors could find only three wild species of Musa vir, M. acuminata, M. balbisiana, M. indandamanensis in DEGCA, BSI, ANRC which are fully established and growing under ex situ conservation. In addition, we could not locate any individual of $M$. paramjitiana during the visits to Musa farm of CIARI during 2014 - 2019, despite, we found there the wild form of M. balbisiana. Bohra et al. (2019) seems to have wrongly identified one or more plant as $M$. paramjitiana, having no idea about its distinguishing/ diagnostic characters.

Apart from the type localities, there was no data on the occurrence of the species in other localities. Therefore, the present authors strongly feel that habitat status of M. paramjitiana needs adequate review and reassessment to the correct status of threat as per IUCN guideline. Hence, during the present study, authors thoroughly examined the type localities of M. paramjitiana in comparison with other existing populations of Musa species in the Islands to discover its new habitat-localities.

\section{MATERIALS AND METHODS}

The present study has been carried out by field surveys during 2014 - 2019, reviewing available relevant literatures as well as open-ended questionnaire to the villagers and forest department people of ANI's.Participatory rural appraisals as well as interaction with wildlife workers were also done to validate the findings. 


\section{RESULTS}

Musa paramjitiana L.J. Singh was described based on the specimens collected in 2013 from Krishnapuri, north Andaman $\left(13^{\circ} 1536.92 \mathrm{~N}, 092^{\circ} 5617.32 \mathrm{E}, \pm 32 \mathrm{M}\right)$ and Kaushalaya Nagar, middle Andaman $\left(12^{\circ} 3157.52 \mathrm{~N}, 092^{\circ} 5000.02 \mathrm{E}, \pm 12 \mathrm{M}\right)$ as an endemic species. The species was assessed as 'Critically Endangered' in 2016 based on collection of 2013 by applying criteria $\mathrm{B}$ of IUCN (restricted distribution range).The threats on the species observed during 2013 visit articulate over-exploitation by local people for manifold value and staple food for elephants.

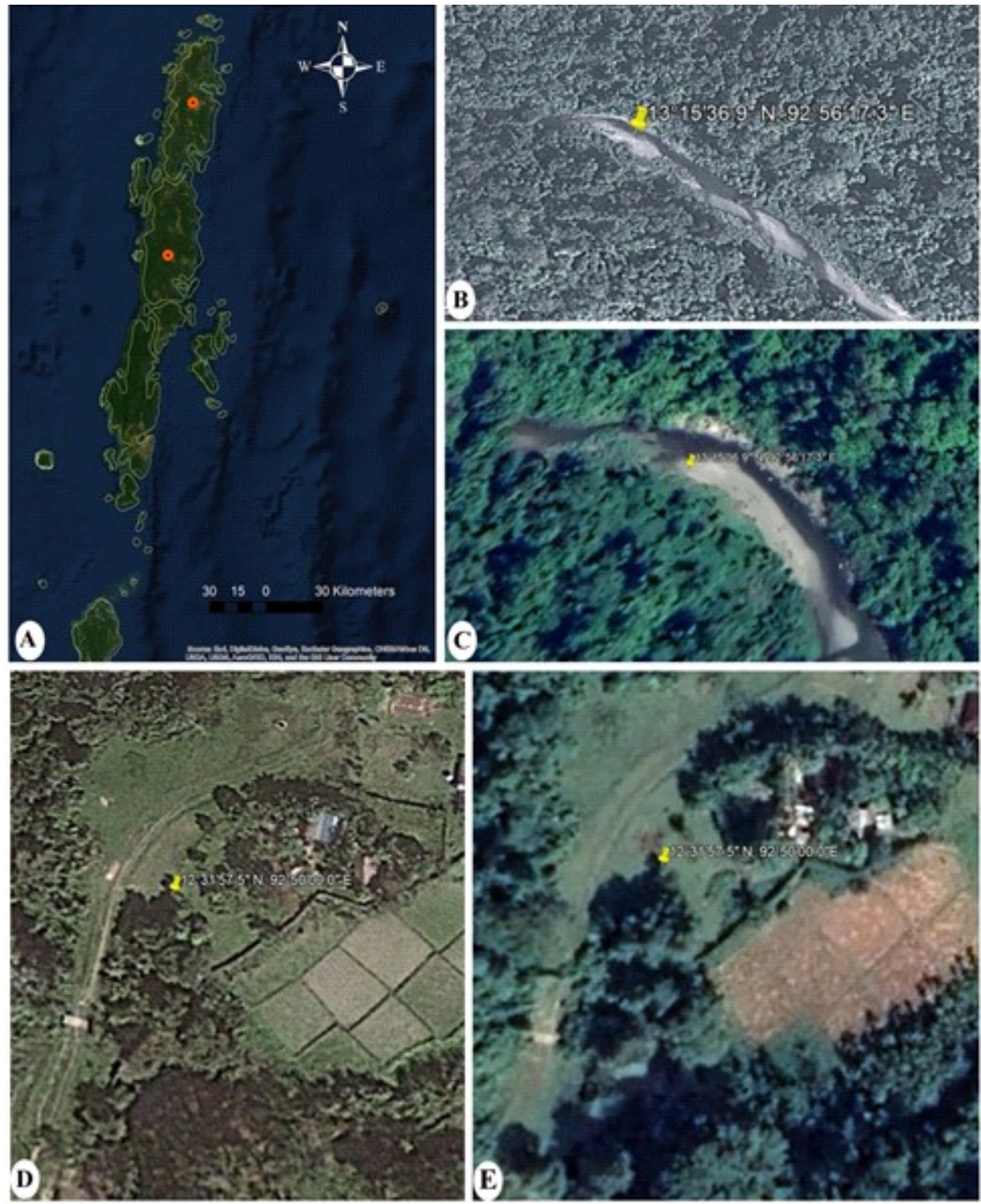

Figure 1. Musa paramjitiana L.J. Singh: A. Satellite imagery of Andaman \& Nicobar Islands showing type locality (Krishnapuri \& Kaushalaya Nagar); B. Satellite imagery of type locality (Krishnapuri: in 2013) showing vegetation structure; C. Satellite imagery of type locality (Krishnapuri: in 2019) showing distribution of vegetation; D. Satellite imagery of type locality (Kaushalaya Nagar: in 2013) showing vegetation structure; E. Satellite imagery of type locality (Kaushalaya Nagar: in 2019) showing vegetation structure. 

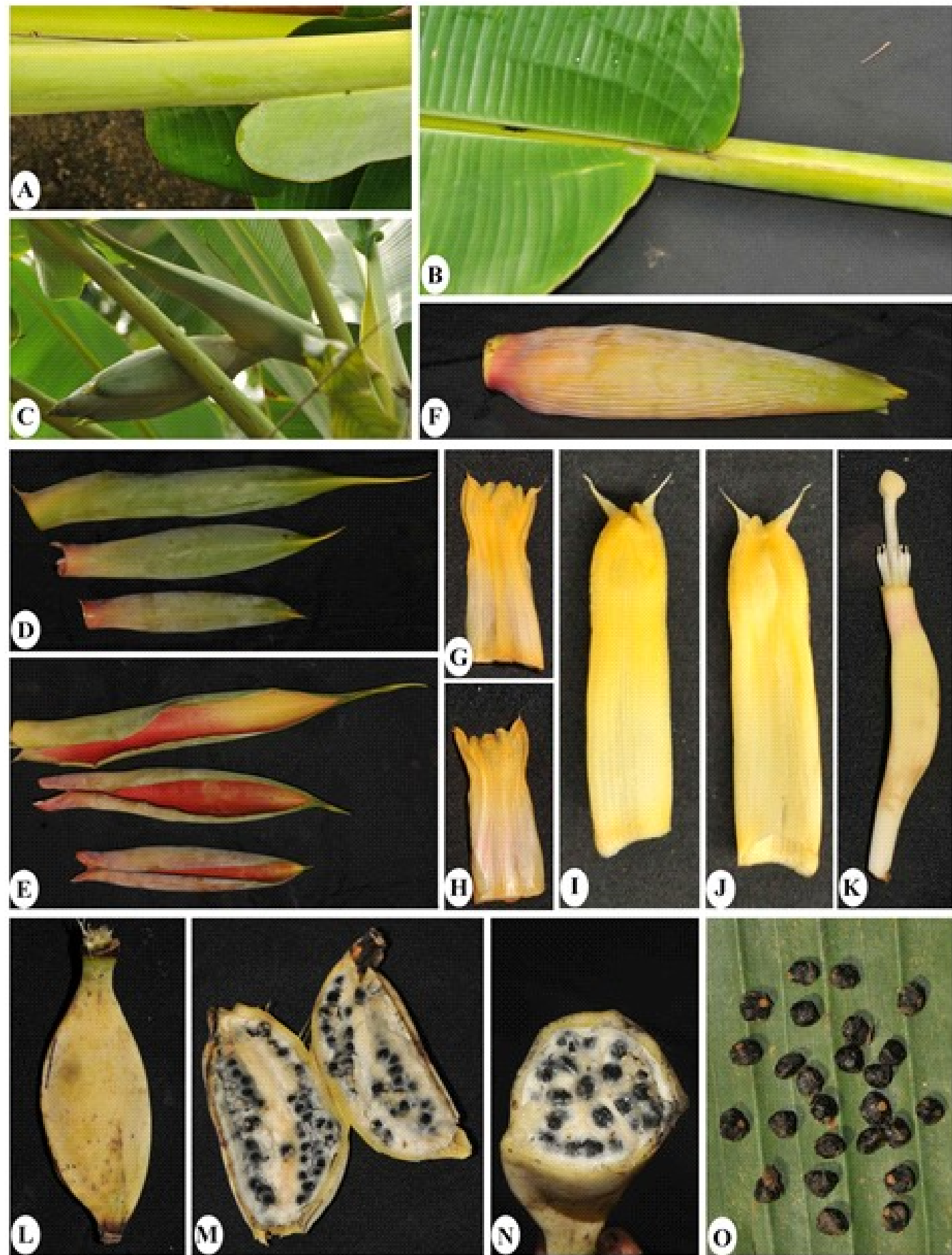

Figure 2. Musa paramjitiana L.J. Singh (photographs from protologue): A-B. petiole with leaf base; C. inflorescence; D-E sterile bracts: dorsal and ventral view; F. fertile bract; G-H. compound tepal: dorsal and ventral view; I-J. free tepal: dorsal and ventral view; K. pistil; L-N. fruits; O. seeds. 
It was also observed the free suckering and multiplication of the species both from rhizome and from seeds in the type locality. Few individuals ( 3 rhizomes and 23 seedlings) were collected from the population and the germplasm were introduced at DEGCA, BSI, ANRC in the month of February 2013 but could not acclimatise under ex-situ condition. Further, five rhizomes and 10 seedlings of the species were collected in the month of October, 2013 and introduced in the Garden but could not survive and dies out within January, 2014. It was observed in 2013 that the seedlings in the type locality were healthy and the microclimatic condition appeared to be highly supported the species to establish easily. Subsequent efforts were made to locate more population of the species in areas other than type localities in the ANI's but could not yield a positive result. The known habitat of this species in the type localities was surveyed again during 2014 to 2019, but not even a single individual of this species could be located. It was found that the known habitat was disturbed substantially by the local inhabitants for human settlements especially by the Ranchi tribe and refugee settler from Bangladesh and Peninsular India. Interview with the village people revealed that, the stems of M.paramjitiana and other wild banana species were cut by the locals (especially Tamil \& Bengali settlers) for decoration on various religious and ceremonial rituals.

Increased developmental activities including road construction in the forest areas and creation of farm land along with over exploitation of natural resources led to the loss their habitats (Figure 1). No further study in the flora of ANI's could provide convincing evidence on the existence of $M$. paramjitiana in the wild. As there is no single living individual left in the type locality and not located in any other natural habitat, its threat status has been reassessed as 'Possibly Extinct' in the present study.

The distinguishable characters of $M$. paramjitiana from the other Musa species include the leaf lamina obliquely subcordate at base and cuspidate at apex, spathe lanceolate with sage bract; erect, first vertical and then falling horizontally downwards, sterile bract with very long attenuate apex, fertile bract with umbulate apex, compound tepal orange, glove-shaped, striated with cuspidate lateral lobes ending in a fine thread like structure, free tepal margins curved inwards and loosely clasping with two lateral horn like structures, pin-eyed stamen, ovary with orbicular stigma, boat shaped fruit with apricot-coloured pulp and fig or bulb shaped seeds. All these characters have been elaborated with more details including figures in the protologoue (Figure 2). Anatomically, M. paramjitiana can be distinguished from other species by connate petiole margins, adaxial hypodermis single layered of thick-walled sclerenchyma, mesophyll consisted of the palisade and spongy tissues, mid-rib consists of 7 schizo-lysigenous cavities of which central two are larger and arranged symmetrically and size of cavities decreasing towards periphery, xylem with one or two large central vessels. Bundle sheaths capped by fibers both adaxially and abaxially

\section{CONCLUSION}

After the recent five-years (2014 - 2019) long search, no living individual of Musa paramjitiana was spotted, neither in its natural habitat nor in any $e x$-situ conservatory. Under this situation, authors reassessed its status for IUCN threat category and flagged the species as 'Possibly Extinct'. The species requires thorough field surveys in the other suitable habitats in the coming years for its relocation and for avoiding further tagging of 'Extinct in the Wild'. New habitats may also be searched with the help of 'Ecological Niche Modelling.' Once it is rediscovered, the species need to be multiplied in-vitro and be reintroduced at suitable habitat-areas to prevent it from extinction.

The fast increasing human population and subsequent demand on natural resources including development related activities, other wild species of Musa are also vanishing from the 
ANI archipelago. This has already been stated earlier by Singh (2014 \& 2017) and any such measure to protect wild bananas, automatically, other elements of biodiversity of the area will be protected in this Hotspot region.If such conservation activities are not initiated immediately, many other interesting species including important gene-pools will also get vanished with time from the Andaman and Nicobar Islands.

\section{Acknowledgements}

The authors are grateful to Dr. A. A. Mao, Director, Botanical Survey of India for his constant support and facilities provided. Authors are grateful to Prof.(Dr.) A. K. Pandey, Vice-Chancellor, Mansarovar Global University, for his valuable inputs for the manuscript. They are also thankful to the anonymous reviewers for critical comments and suggestions. Authors extend thanks to the Department of Environment and Forests, Andaman and Nicobar Islands for granting permission necessary help during the field studies. The technical supports by Dr. D.K. Agrawal, BSI, SHRC is also thankfully acknowledged.

\section{LITERATURE CITED}

Argent, G.C.G.1976. The wild bananas of Papua New Guinea. R. Bot. Gard. Edinb. 35: 77-114.

Bohra, P.; Waman, A.A. \& Jerard, B.A. 2019. Accelerating regeneration of threatened wild banana (Musa paramjitiana L.J. Singh) endemic to Andaman and Nicobar Islands, India Current Science, 116: 1792 - 1794

Dey, S.; Jamir, N.S.; Gogoi, R.; Chaturvedi, S.K.; Jakha, H.Y.; Zubenthung P.\& Kikon, Z.P. 2014. Musa nagalandiana sp. nov. (Musaceae) from Nagaland, northeast India. Nordic Journal of Botany 32(5): 584 - 588.

Gogoi, R. \& Borah, S. 2014. Musa argentii (Musaceae), A new species from Arunachal Pradesh, India. Edinburgh Journal of Botany 71( 2 ): 1 - 8.

Gogoi, R. \& Häkkinen, M. 2013a.Musa puspanjaliae (Musaeae), a new species from Arunachal Pradesh, India. Nordic Journal of Botany 31(4): 473 - 477.

Gogoi, R. \& Häkkinen, M. 2013b.Musa kamengensis (Musaceae), a new species from Arunachal Pradesh, India. Acta Phytotaxonomica et Geobotanica. 64(2): 127-131

Gogoi, R.; Häkkinen, M.; Borah, S. \& Satyanarayana, P. 2014. Taxonomic identity of Musa cheesmanii (Musaceae) in northeast India. Nordic Journal of Botany 32(4): 474 - 478.

Häkkinen, M. 2009. Musa chunii Häkkinen, a new species (Musaceae) from Yunnan, China and taxonomic identity of Musa rubra. Journal of Systematics and Evolution 47(1): 87 - 91.

Hakkinen, M. 2013. Reappraisal of sectional taxonomy in Musa (Musaceae). Taxon, 62(4): 809 -813 .

Häkkinen, M. \& Väre, H. 2008. Typification and check list of Musa L. names (Musaceae) with nomenclature notes. Adansonia 30: 63 - 112.

Häkkinen, M.; Gogoi, R. \& Borah, S. 2014. A taxonomic study of Musa flaviflora and M. thomsonii (Musaceae). Nordic Journal of Botany 32(5): 578 - 583.

Haines, H.H. 1910. Musaceae. In: Forest flora of Chota Nagpur. Dehra Dun: Bishen Singh Mahendra Pal Singh, Dehra Dun. Pp. 536-537.

Hareesh, V.S.; Joe, A.; Alappatt, J.P. \& Sabu, M. 2017. Musaceae of Andaman and Nicobar Islands with two new synonyms and one distributional records. Rheedea 27(20): $71-78$

Hore, D.K.; Sharma, B.D. \& Pandey, G. 1992. Status of banana in North East India. Journal of Economic and Taxonomic Botany, 16(2): 447 - 455. 
Linnaeus, C.1753. Species Plantarum ed. 2. Stockholm: Impensis Laurentii Salvii.

Naik, M. C.; Ekka,G.A.; Dwivedi, Mayank D. \& Kasana, S. 2019. Systematics of the Genus Musa L. (Zingiberales: Musaceae) from Andaman and Nicobar Islands. In: International Conference on Advances in Sustainable Agriculture Bioresources, Biotechnology and Bioeconomy. Bhopal, M.P., India. pp. 72

Roxburgh, W. 1814. Hortus Bengalensis. Leiden (Holland): Boerhaave Press.

Singh, L.J. 2014. Musa indandamanensis L.J. Singh, a new species of wild banana genus Musa (Musaceae) from Bay Islands, India. Taiwsania 59: $26-36$.

Singh, L.J. 2017. Musa paramjitiana sp. nov. (Musaceae) from Andaman and Nicobar Islands, India. Nordic Journal of Botany 35(1): $77-84$.

Singh, L.J.; Murugan, C. \&Singh, P. 2014. Plant genetic diversity of endemic species in the Andaman and Nicobar Islands. In: Nat. Conf. on Islands Biodiv., U. P. State Biodiversity Board, Lucknow. Pp. $49-57$.

Singh, D.B.; Sreekumar, P.V.; Sharma, T.V.R.S. \& Bandyopadhyay, A.K.1998. Musa balbisiana var. andamanica (Musaceae) - A new banana variety from Andaman Islands. Malayan Nat. J. 52(3 \& 4): $157-160$.

Singh, L.J.; Mishra, S.; Vivek, C.P. \& Ekka, G.A. 2018. Systematic Account of Family Musaceae in the Andaman and Nicobar Islands. In: H.K. Chourasia \& D.P. Mishra (eds.), Plant Systematics and Biotechnology: Challenges and Opportunities. Today and Tomorrow's Printers and Publishers, New Delhi. Pp.473 - 483.

Singh, L.J.; Dwivedi, M.D.; Kasana, S.; Naik, M.C.; Ekka, G.A. \& Pandey, A.K. 2020. Molecular systematics of the genus Musa L. (Zingiberales: Musaceae) in Andaman and Nicobar Islands. in press. 